\title{
Sprawozdanie
}

\section{Międzynarodowa Konferencja Naukowa „Systemy ochrony praw człowieka: europejski i afrykańskie. Kontekst uniwersalny - specyfika regionalna - uwarunkowania realizacyjne”, Warszawa, Sejm, 17-18 marca 2016 r.}

W dniach 17-19 kwietnia 2016 r. w Warszawie odbyła się międzynarodowa konferencja naukowa pod tytułem „Systemy ochrony praw człowieka: europejski i afrykańskie. Kontekst uniwersalny - specyfika regionalna - uwarunkowania realizacyjne". Okazję dla doboru tematu stanowiły 50 rocznica podpisania Międzynarodowych Paktów Praw Człowieka oraz 35 rocznicy podpisania Afrykańskiej Karty Praw Człowieka i Ludów. Już ósma edycja Konferencji zgromadziła w Sejmie ponad 300 uczestników, z czego 180 osób wygłosiło referat. Tak duże wydarzenie wymagało nie tylko sprawnego przygotowania logistycznego, ale również zapewnienia poziomu naukowego, których gwarantami byli kierownik naukowy Konferencji prof. dr hab. Jerzy Jaskiernia oraz kierownik organizacyjny dr Kamil Spryszak. Dzięki ich osobistemu zaangażowaniu i koordynacji pracy szeregu osób możliwym było kolejny raz przeprowadzenie Konferencji o zasięgu światowym. I nie ma w tym słowa przesady, albowiem swoją obecnością zaszczycili uczestników nie tylko najwybitniejsi przedstawiciele polskiej nauki prawa, najwyższych organów państwowych, czy goście z krajów Europy. Wśród uczestników byli bowiem także Mohamed Aly Aidara z Institut Mozdahir International w Dakarze w Senegalu, dr hab. Tomasz Milej z University of 
Dar es Salaam, Tanzania (również pracownik naukowy Uniwersytetu Zielonogórskiego), jak też dr Rzumabek Djusewicz Busurmanow, profesor Akademii Nauk Prawnych Republiki Kazachsko-Euroazjatyckiego Narodowego Uniwersytetu im. L.N. Gumilewa w Astanie.

$\mathrm{Na}$ uwage zasługuje fakt, że organizatorzy w swoich wysiłkach potrafili umiejętnie włączyć do porządku obrad także adeptów nauki prawa - nie tylko doktorantów, ale także studentów. Organizatorami Konferencji byli Uniwersytet Jana Kochanowskiego w Kielcach (Instytut Prawa, Ekonomii i Administracji), Stowarzyszenie Parlamentarzystów Polskich oraz European Association of Former Members of Parliament of the Council of Europe Member States. Międzynarodowy charakter wydarzenia wynikał nie tylko ze współorganizacji przez podmioty z różnych krajów, czy przedstawicieli państw z całego świata, ale także języków Konferencji, którymi były języki polski, angielski i rosyjski.

Wielość uczestników sprawiła, że obrady należało podzielić na dwa dni. Uczestnicy Konferencji dosłownie „opanowali” Sejm. Poszczególne referaty wygłoszono w 4 sesjach plenarnych oraz 16 obradach panelowych. Sesje plenarne zaszczycili swoją obecnością najwybitniejsi przedstawiciele nauki. W ramach obrad plenarnych zajmowano się aksjologią i instytucjami ochrony praw człowieka w Afryce, praktyką ochrony praw człowieka w Afryce i instrumentami wsparcia międzynarodowego, kluczowymi wyzwaniami międzynarodowego systemu ochrony praw człowieka oraz rozważano na temat zwiększenia efektywności międzynarodowego i krajowych systemów ochrony praw człowieka. Ponieważ temat Konferencji obejmował nie tylko zagadnienia związane z ochroną praw człowieka w Afryce, ale też w Europie obrady panelowe dotyczyly szerszego zakresu problemowego. Stąd poruszano kwestie dotyczące nie tylko problemu ochrony praw człowieka w Afryce (aż cztery panele), ale także te odnosząc się do zagadnień europejskich - analizowano ochronę praw człowieka w systemie Rady Europy, UE i OBWE, jak też zajmowano się tendencjami rozwojowymi międzynarodowego systemu ochrony praw człowieka. Za przedmiot rozważań w części paneli obierano także poszczególne prawa. Pogłębionym dyskusjom poddano m.in. prawo do życia, zdrowia i ochrony środowiska, jak też prawo do sądu, czy prawo do bezpieczeństwa i ochrony praw człowieka w procedurach karnych. Dyskusje toczono także w panelach poświęconych poszczególnym generacjom praw człowieka. 
Pierwszego dnia Konferencji w restauracji Avangarda odbyła się uroczysta kolacja połączona z prezentacją książek z ubiegłorocznej konferencji. Kolacja stała się doskonałą okazją dla przybliżenia celów tegorocznego spotkania naukowego. Miała ona również swój wymiar towarzyski, pozwalając jeszcze przed rozpoczęciem obrad zapoznać się między sobą uczestnikom spotkania.

Poniedziałkowy poranek 18 kwietnia 2016 r. rozpoczęło zwiedzanie Sejmu. Następnie przyszedł czas na ceremonię otwarcia obrad. Pierwsze słowa do zgromadzonych wygłosił prof. dr hab. Jerzy Jaskiernia, dyrektor Instytutu Prawa, Ekonomii i Administracji Uniwersytetu Jana Kochanowskiego w Kielcach, marszałek Stowarzyszenia Parlamentarzystów Polskich. Odniósł się w swoim wystąpieniu do historii obrad. Przypomniał, że obejmuje ona również tragiczne wydarzenia z 10 kwietnia 2010 r. Tego dnia w Sejmie także zgromadzili się referenci na obradach. Słowo powitalne wygłosili też Prorektor Uniwersytetu Jana Kochanowskiego w Kielcach Pani dr hab. prof. UJK Barbara Zbroińska oraz prezes Najwyższej Izby Kontroli Pan Krzysztof Kwiatkowski. Na szczególną uwagę zasługuje wystąpienie powitalne Wicemarszałek Senatu RP Pani Marii Koc. Przedstawiła ona szerokie i bogate wprowadzenie do problematyki obrad, po którym każdy z uczestników doskonale orientował się w zakresie tematu Konferencji. Przewodniczący Wydziału I Izby Karnej Sądu Najwyższego Pan Stanisław Zabłocki reprezentujący Sąd Najwyższy w zastępstwie pierwszej prezes prof. dr hab. Małgorzaty Gersdorf przypomniał, że status suwerennego państwa wymaga przestrzegania praw i wolności zawartych w Konstytucji RP, jak i tych wynikających z paktów międzynarodowych. Zaś przesłanie Rzecznika Praw Dziecka, Marka Michalaka odczytał Pan prof. dr hab. Leszek Stadniczeńko. Przypomniał on zgromadzonym, że prawa dziecka - niezależnie od tego, gdzie ono mieszka - wszędzie są takie same. Mając na uwadze międzynarodowy wymiar Konferencji oraz problemy ochrony praw dziecka we współczesnym świecie słowa przedstawiciela RPD stanowiły ważne wskazanie dla podejmujących obrady.

Nie sposób przywołać tezy wszystkich referatów wygłoszonych podczas Konferencji. Wskazani poniżej uczestnicy oraz przedstawione przez nich zagadnienia nie wyczerpują całości bogatej problematyki i szerokiego spektrum zainteresowań samych uczestników. Niestety ramy sprawozdania 
pokonferencyjnego nie pozwalają - z uwagi na rozmiar Konferencji - na odniesienie się do każdego z wystąpień.

Wyszczególnić wypada, po pierwsze, wystąpienie prof. dra hab. J. Symonidesa, który wskazał na specyfikę i rozwój afrykańskiego systemu ochrony praw człowieka. Zauważył on, że rocznicowy wymiar, na który wskazał prof. J. Jaskiernia, stanowi doskonałą sposobność do oceny przyjętych regulacji i ich realizacji. Wśród sukcesów wskazał na wybieganie przez postanowienia Afrykańskiej Karty Praw Człowieka i Ludów w przyszłość, jej postępowy charakter. Rzeczowo przedstawił mankamenty ochrony praw człowieka nią ustanowionych, wśród których wymienił przede wszystkim liczne odesłania do prawa wewnętrznego poszczególnych państw oraz słaby system nadzoru przestrzegania jej przepisów. Wielokrotnie również przypomniał o aspekcie finansowym i jego wpływie na prawidłowość wykonywania postanowień Karty. Pan prof. J. Symonides w sposób systematyczny wskazując na rozwój afrykańskich systemów ochrony skonstatował, że sytuacja w obszarze ochrony prac jednostki w Afryce jest wciąż daleka od doskonałości. Niemniej jednak rola już obowiązujących uregulowań i ich upowszechnianie są nie do przecenienia. Bez nich, jak stwierdził prof. J. Symonides, sytuacja byłaby znacznie gorsza. Zwracając się do zebranych przypomniał o roli wiedzy o prawach człowieka dla gwarantowania ich ochrony, albowiem mogą one być przestrzegane tylko wtedy, kiedy są one znane.

Kontekst ekonomiczny przywołał w swoim referacie także prof. dr hab. Wojciech Pomykało. Swoim wystąpieniem przypomniał zgromadzonym, że w wielu przypadkach to narody afrykańskie stworzyły podstawy sukcesu dzisiejszych krajów kapitalistycznych. Walor historyczny jest o tyle istotny, że mając na uwadze powyższe na państwach europejskich i USA spoczywa szczególne zobowiązania - $\mathrm{w}$ tym również zobowiązanie do pomocy w kształtowaniu poszanowania praw człowieka w Afryce.

Ze szczególną atencją uczestnicy Konferencji wysłuchali referatu dra hab. prof. UZ Andrzeja Bisztygi zatytułowanego Charakterystyka afrykańskiego systemu ochrony praw człowieka. Geneza, instytucje, specyfika. Jak na wstępie swojego wystąpienia zaznaczył prof. A. Bisztyga, opracowanie stanowiło próbę poszukiwania źródeł godności człowieka w okresie przedkolonialnym i kolonialnym. Pan prof. A. Bisztyga wskazywał na przykłady rozwiązań prawnych, które nie są powszechnie znane. $\mathrm{Z}$ uwagą słuchano o roli ogło- 
szonej w 1236 r. jednej z pierwszych deklaracji praw człowieka. Deklaracja znana jako Charte de Kouronkan Fonga lub jako Charte du Mande wydana w byłym cesarstwie Mali przez Soundiatę Keita, mając na celu umocnienie pokoju w cesarstwie, została przyjęta aż przez trzynaście narodowości imperium. Już wówczas zawarto w niej postanowienia dotyczące solidarności społecznej, ochrony praw kobiet, prawa do życia i fizycznej nietykalności, czy też ochrony przyrody. Interesującym wątkiem były także rozważania na temat roli religii w kształtowaniu rozwiązań z zakresu ochrony praw człowieka. Pan prof. A. Bisztyga zaprezentował w podsumowaniu w sposób zwięzły i klarowny podstawowe konkluzje wyrażające zadania stawiane odpowiedzialnym za kształtowanie ochrony praw człowieka w Afryce. Przypomnieć wypada za referentem, że, po pierwsze, skuteczna ochrona praw człowieka w Afryce może być urzeczywistniania tylko w kontekście praw ludów. Po drugie, w Afryce należy wyraźnie odróżniać od warstwy normatywnej warstwę praktyczną. Po trzecie, ustanowienie i ewolucja afrykańskich systemów ochrony praw człowieka sama w sobie nie przyniesie zamierzonego skutku. Koniecznym jest bowiem wsparcie w postaci zastosowania odpowiednich środków legislacyjnych - głównie o charakterze krajowym. Niezbędne jest zapewnienie kompatybilności rozwiązań normatywnych. Samo wprowadzanie przepisów okazać się może jednak niewystarczające, jeżeli idea praw człowieka nie będzie upowszechniana, głównie poprzez edukację - ze wskazaniem na rolę, jaką odegrać powinny organizacje pozarządowe. I wreszcie, po czwarte, inicjatywy zmierzające do wzmocnienia ochrony i promocji praw człowieka podejmować należy z poszanowaniem rodzimych tradycji i ich osiągnięć. Nie sposób nie przyznać racji postawionym tezom.

Jeszcze trudniej odnieść się do wszystkich 180 referatów wygłoszonych podczas obrad prowadzonych w 16 panelach. $Z$ tej przyczyny przywołane zostaną te, które spotkały się ze szczególnym zainteresowaniem pozostałych uczestników oraz te, nad którymi podejmowano gorące dyskusje. W pierwszej kolejności wypada wspomnieć o referacie dr Krystyny Ziółkowskiej z Uniwersytetu Warmińsko-Mazurskiego w Olsztynie poświęconym wolności zrzeszania się jako podstawowym prawie pracownika na podstawie polskich i unijnych przepisów. W tym przypadku przyczynek do dyskusji stanowił wyrok Trybunału Konstytucyjnego z 2 czerwca 2015 r. w sprawie K 1/13. 
Rozważano wątpliwości w zakresie skutku wyroku dla rozumienia wolności koalicji, w szczególności o przyszłości nowelizacji art. 2 ustawy o związkach zawodowych, która $\mathrm{z}$ uwagi na zapadłe rozstrzygnięcie musi zostać przeprowadzona. Zastanawiano się, czy zakres podmiotowy wolności koalicji nie powinien również objąć osób odbywających służbę zastępczą czy też wolontariuszy lub osób odbywających staż. W obszarze prawa pracy z zainteresowaniem spotkały się tezy wysunięte przez dra Piotra Kapustę z Uniwersytetu Zielonogórskiego. Referent wskazał, że ustawodawca bardzo często niewłaściwie dekoduje przepisy Konstytucji RP a przez to niewłaściwie odczytuje się konstytucyjne obowiązki państwa w zatrudnieniu. W ocenie dra P. Kapusty konstytucyjne konteksty użycia sformułowań odnoszących się do pracy i zatrudnienia należy interpretować różnie. Choć w nauce mamy do czynienia z pojęciami zastanymi, to jednak pojęcia konstytucyjne powinny być rozumiane zazwyczaj autonomicznie. Jego zdaniem postulować należy wyodrębnienie nowej gałęzi prawa - prawa zatrudnienia. Wypracowanie jego zasad, spójnych z aksjologią Konstytucji - przy poszanowaniu modelu zatrudnienia pracowniczego, pozwoli na unikanie błędów popełnianych obecnie.

Z dużą uwagą przyjęto wystąpienie dr Magdaleny Kornak z Wyższej Szkoły Prawa im. Heleny Chodkowskiej we Wrocławiu poświęcone prawu oskarżonego do obrony w orzecznictwie ETPC. Uczestnikom przypomniano podstawową kwestię, że przyjęty kształt zasady prawa do obrony sprawia, że zasada ta obejmuje szereg uprawnień procesowych pozwalających tak na osobistą walkę oskarżonego z postawionymi zarzutami (obrona materialna), jak i korzystanie z pomocy fachowej obrońcy (obrona formalna). Obrona może przybrać bowiem zarówno postać obrony merytorycznej, czyli zwalczania zarzutów bezzasadnych, jak też obrony stricte procesowej, nastawionej na instrumenty proceduralne chroniące oskarżonego, bez podważania samego zarzutu. Wielość zagadnień spowodowała, że referentka ograniczona ramami czasowymi zmuszona była podać jedynie przykłady realizacji i gwarancji prawa do obrony na gruncie art. 6 EKPC i orzecznictwa. Podczas wystąpienia przypomniała również, ̇̇e ETPC wielolkrotnie wskazywał, $\dot{z}$ e art. 6 EKPC powinien mieć zastosowanie również do postępowania przedsądowego. Gwarancje wynikające z art. 6 przysługują w wytoczonej przeciwko osobie sprawie karnej także na etapie postępowania przygotowawczego, 
od chwili skierowania względem niej ścigania. Co ciekawe jednak, prawo do obrony osobistej przysługujące oskarżonemu w każdym stadium postępowania może jednak podlegać pewnym ograniczeniom. Państwo może bowiem w określonych przypadkach wymagać, aby korzystał z pomocy obrońcy dla dobra wymiaru sprawiedliwości w procesie przed sądem I instancji lub w instancji odwoławczej. Dyskusja pokazała, że pokonferencyjne opracowanie wystąpienia stanowić będzie cenne źródło dla wszystkich, którzy interesują się prawem do obrony, w szczególności że p. dr M. Kornak argumentację budowała w oparciu o liczne orzeczenia ETPC.

Podczas obrad panelu 11 poświęconego ochronie praw człowieka we współczesnych systemach politycznych został poruszony m.in. aktualny i obecnie dyskutowany w doktrynie problem orzekania merytorycznego przez sądy administracyjne. Zagadnienie to przedstawiła dr Justyna Michalska z Uniwersytetu Zielonogórskiego. Określiwszy główne założenia, które przyświecały ustawodawcy, przedstawiła również głosy krytyczne wysuwane jeszcze w procesie pracy na nowelizacją Prawa o postępowaniu przed sądami administracyjnymi, która weszła w $\dot{z} y c i e ~ 15$ sierpnia 2015 r. Niewątpliwie jedną z istotniejszych kwestii dotyczyła na konstytucyjności art. 145a p.p.s.a., na którą to wskazywano jeszcze podczas prac legislacyjnych. Referat stał się w rezultacie przyczynkiem do szerokiej dyskusji nad zgodnością art. 145a p.p.s.a. z art. 2, art. 10 i art. 184 Konstytucji RP.

Pośród zagadnień referowanych podczas obrad panelowych szeroko dyskutowany był, w tym również podczas wieczornych spotkań, referat dr Agnieszki Kos z PWSZ w Legnicy. Poruszyła ona temat praw kobiet na kontynencie afrykańskim w kontekście równości płci. W wystąpieniu poruszono problem dyskryminacji płci w Afryce na wielu płaszczyznach. Przywołała ona proceder obrzezania, porusza problem honorowych zabójstw oraz dyskryminacji płciowej w aspekcie partycypacji obywatelskiej płci żeńskiej w życiu i funkcjonowaniu państwa. Temat wywołał na tyle szeroką dyskusję, że przeniesiono się na kontynent azjatycki i zagadnienia związane z gendercide, które nazwano - w ślad za Parlamentem Europejskim - współczesną formą ludobójstwa. Referat oprócz swej warstwy naukowej miał głęboki wydźwięk humanitarny, wskazujący na okrutny los setek tysięcy afrykańskich kobiet. Pozostaje mieć nadzieję, że wyrażone konkluzje pozwolą przyczynić się do poprawy ich losu. 
Uwagę słuchaczy skupił również referat dotyczący działalności europejskich organizacji ochrony praw człowieka w państwach Azji Centralnej na przykładzie OBWE mgra Grzegorza Nizioła - doktoranta Wydziału Politologii Uniwersytetu Marii Curie-Skłodowskiej w Lublinie, wykładowcy w Zakładzie Stosunków Międzynarodowych Wyższej Szkoły Stosunków Międzynarodowych i Komunikacji Społecznej w Chełmie, zastępcy prezesa Stowarzyszenia przyjaźni polsko-uzbeckiej „Przyjaźń-Dustlik”. Przybliżono nim obszary działania Organizacji w poszczególnych republikach Azji Centralnej: Kazachstanie, Kirgistanie, Tadżykistanie, Turkmenistanie i Uzbekistanie. Postawiono jednocześnie tezę, iż działalność ta jest dalece nieefektywna ze względu na specyfikę regionu, autorytarne rządy, dominująca rolę systemu patronalno-klientalnego oraz wszechobecną korupcję. Stąd też przy tak silnie działających sieciach powiązań i hermetyczność grup przestępczych, jak też zakorzenienie w kulturze korupcji jest ogromne skuteczna walka z nimi jest dalece utrudniona. Dlatego umacnianie bezpieczeństwa i współpracy w trzech wymiarach: polityczno-wojskowym, ekonomiczno-środowiskowym i ludzkim, jest wyjątkowo trudne, tym bardziej, że deklaracje i decyzje podejmowane przez OBWE mają charakter polityczny i nie są prawnie wiążące. Jako najważniejsze wyzwania dla OBWE w Azji Centralnej prelegent wskazał działania na rzecz rozwoju przejrzystego procesu wyborczego, rozwoju swobód politycznych, ochrony praw człowieka, podnoszenia poziomu edukacji, podnoszenia aktywności gospodarczej opartej na gospodarce wolnorynkowej i przeciwdziałaniu prania brudnych pieniędzy, zapobiegania i rozwiązywania konfliktów związanych m.in. z właściwym gospodarowaniem zasobami wodnymi w regionie, zwalczania fundamentalizmu islamskiego i walki z międzynarodowym terroryzmem, walki ze zorganizowaną przestępczością, obrotem środkami odurzającymi i handlem ludźmi, ochrony granic państwowych, poprawy skuteczności działania w obszarze ochrony środowiska, wprowadzania reform i współpracy w sektorze bezpieczeństwa, kontroli przestrzegania ogólnych zasad praworządności czy działań na rzecz równości płciowej. Podsumowując prelegent wskazał, że zmiany wytyczane przez standardy OBWE dokonywać się będą powoli a także, że czytając raporty oraz opracowania na temat Azji Centralnej i dokonując oceny należy pamiętać, że bywają one skażone błędem europocentryzmu czy globalizmu (zwłaszcza opracowania spoza Azji Centralnej) 
albo błędem panegiryzmu lub subiektywizmu w wypadku opracowań autorów z Azji Centralnej.

$\mathrm{Z}$ niemałym zainteresowaniem spotkało się wystąpienie przedstawicieli Ministerstwa Sprawiedliwości mgr Magdaleny Malinowskiej-Wójcickiej i mgra Hieronima Ostrowskiego poświęcone prawu do mieszkania. Referenci zaprezentowali nie tylko stan regulacji prawnej, ale odnieśli się również polskiej praktyki w świetle EKPC i Konstytucji RP. Wystąpienie stało się początkiem ożywionej dyskusji nad konstytucyjnymi obowiązkami państwa w zakresie działań w zakresie zaspokajania potrzeb mieszkaniowych jednostek. Wszyscy uczestnicy dyskusji byli zgodni co do tego, że konstytucjonalizacja polityki mieszkaniowej czyni ją obowiązkiem władzy publicznej, co jeszcze nie przesądza o tym, że automatycznie pociągnie za sobą ustanowienie podmiotowego prawa do mieszkania. Choć z orzecznictwa wynika programowy charakter przepisu art. 75 Konstytucji RP przywołano interesującą koncepcję prof. J. Trzcińskiego głoszącą tzw. minimum praw obywatelskich w normach programowych. Wszyscy zainteresowani będą zapewne z niecierpliwością oczekiwać na opracowanie pokonferencyjne, które poświęcone zostanie tej tematyce.

Sejmowa Konferencja zgromadziła kolejny raz pośród swoich uczestników przedstawicieli różnych nauk. Oprócz będących w większości prawników znaleźli się również m.in. filologowie, psycholodzy czy studenci AWF. W tym kontekście wspomnieć wypada o referacie poświęconym problemowi implementacji standardów europejskich do afrykańskich systemów ochrony praw człowieka Pana Dawida Kołodzieja, prezes Polskiego Towarzystwa Psychopedagogicznego Poradni Terapeutyczno-Couchingowa w Bolesławcu. Przedstawił on trudności związane z wdrażaniem kwestii prawnych, kulturowych i społecznych w krajach afrykańskich. Wystąpienie wzbogacone było o przedstawienie obecnej sytuacji w Afryce w analizowanym zakresie. Do grupy tej zaliczyć także należy wystąpienie lic. Dawida Kutryna. Odniósł się on do prawa do zmiany miejsca pracy w 20 lat po sprawie Bosmana. Referat ten ukazał, że prawa człowieka związane są z codziennym funkcjonowaniem każdego człowieka i nie znają one ni granic państwowych, ani ograniczeń zawodowych. Mamy bowiem z nimi do czynienia w każdym aspekcie działań podejmowanych przez jednostki i w każdej ze sfer powinny być one respektowane. Zadowolenie budzi, że problematyka praw człowieka obecna 
jest nie tylko w nauce prawa, socjologii czy politologii, ale ich istota dostrzegana jest także przez przedstawicieli innych dyscyplin naukowych. Obecność praw człowieka w ich rozważaniach stanowi dowód sukcesów ich promocji i edukacji obywateli w tym zakresie.

Zamknięcia konferencji dokonał we wtorek 19 kwietnia 2016 r. jej kierownik naukowy prof. J. Jaskiernia. Podziękował on serdecznie za przybycie i aktywny udział w Konferencji. Jeszcze raz wyraził swoje zadowolenie z zainteresowania, jakim od lat żywi się coroczne sejmowe spotkania prawnoczłowiecze. Przypomniał przy tym, że przyszłoroczna konferencja poświęcona zostanie, oprócz tradycyjnego rdzenia europejskiego, problematyce ochrony praw człowiek a Australii i Oceanii. Ponadto - już tradycyjnie - zapowiedział publikację wystąpień prelegentów w formie pracy zwartej, która zapewne obejmować będzie po raz kolejny kilka tomów.

Piotr Kapusta Uniwersytet Zielonogórski 